\title{
Geoquatiu
} Malaysian Joumal of Society and Space

\section{The impact of Covid-19 Movement Control Order on SMEs' businesses and survival strategies}

\author{
Ahmad Raflis Che Omar ${ }^{1}$, Suraiya Ishak ${ }^{2}$, Mohd Abdullah Jusoh ${ }^{3}$ \\ ${ }^{1}$ Fakulti Ekonomi dan Pengurusan, Universiti Kebangsaan Malaysia \\ ${ }^{2}$ Program Sains Pembangunan, Pusat Kajian Pembangunan, Sosial \& Persekitaran, \\ Fakulti Sains Sosial dan Kemanusiaan, Universiti Kebangsaan Malaysia \\ ${ }^{3}$ Fakulti Pengurusan dan Ekonomi, Universiti Pendidikan Sultan Idris \\ Correspondence: Suraiya Ishak (email: suraiya@ukm.edu.my)
}

Received: 01 March 2020; Accepted: 15 May 2020; Published: 30 May 2020

\begin{abstract}
Coronavirus outbreak is the latest world tragedy that have affected all sectors in economy. The lockdown, confinement, limited movement order and social distancing are amongst the preemptive governments' effort to safeguard the public health. While recognizing the importance of the national order in preventing the immense spread of the virus, the authors contend that there are certain undiscovered impacts of the control order policy on SMEs in Malaysia. The objectives of this article are to scrutinize the implications of the Covid-19 Movement Control Order (MCO) on SMEs businesses and to identify survival strategies based on the owners' perspectives. The study applies qualitative approach conducted through phone-based interviews with six selected SMEs' owners during the first phase of control order from March 18, 2020 to March 31, 2020. In summary, the impacts of MCO on SMEs are classified into the operational problems (i.e. operation distruption; supply chain distruption; foresighting the future business direction) and the financial problems (i.e. cash flow imbalance; access to stimulus packages; risk of bankcruptcy). Meanwhile, the major themes of current survival strategies fall under the financial and marketing strategies. The paper recommends few suggestions for future research work, business development agencies and entrepreneurs.
\end{abstract}

Keywords: Covid-19, movement control order (MCO), small and medium enterprises (SMEs), business, strategy

\section{Introduction}

The Covid-19 coronavirus outbreak is a human tragedy affecting billions of people in this world. The outbreak also imposed negative impacts on the global economy, industries, corporations and small and medium enterprises (SMEs). Consequently, economists predict the slowing down of economic activity momentum started from March 2020 onwards without specific ending date (Segal \& Gerstel, 2020). For that reason, this article intends to scrutinize the actual implications of the Malaysian Covid-19 Movement Control Order (MCO) on 
SMEs businesses and to identify the survival strategies based on the responses of SMEs owners. We believe the effects of MCO and strategies are distinctive to individual SMEs. Thus, this study differs from other quick online surveys conducted by business associations and government agencies due to several reasons. First, the study applies semi-structured phone-based interviews with selected SMEs' owners during the first phase of the order (i.e. March 18, 2020 to March 31, 2020). The interview approach allows an in-depth understanding about the issue compared to any online survey or quatitative approach. Besides that, the telephone interview is the safest communication channel during the virus outbreak period and able to gain higher response rate (Jackson, 2008). Secondly, the qualitative approach allows the SMEs operators to share their actual feelings and on the ground experience regarding the impact of the COVID 19 on their businesses. Thus, the study can contribute toward the enhancement of knowledge on SMEs business challenges during the unexpected crisis.

To date, comprehensive statistics and official data about Covid-19 impacts on SMEs in Malaysia are still unavailable at least until the time of this article was wrote. Currently, the Malaysian Statistical Department just launched a special online survey on the effects of Covid-19 on Malaysians and the economy (The Star Online, 2020). The first round of the survey has started from March 23, 2020 until March 31, 2020 and is open to all Malaysians aged above 15 years old. The survey consists of 21 questions in three areas; (1) general information about the respondents, (2) jobs, and (3) public spending. The findings will be used as an input for the government to gauge the spread of the Covid-19 on the economy, employment and expenditure of Malaysian people. Meanwhile, the Marketing Insight (2020), in their quick survey on public reactions in Kuala Lumpur and Penang on the impacts of Movement Control Order (MCO) reveals that SMEs are currently switching their business conduct into online business due to the changes of consumers purchase behavior during $\mathrm{MCO}$ period. Nevertheless, the impacts of MCO on SMEs and the understanding of their survival strategies are equally important to be explored in order to complement the quantitative insights.

Therefore, this study is timely important to achieve three main agendas. First, is to provide clear insights on the early impact of Covid-19 outbreak and MCO on SMEs. Second, is to identify early survival strategies among SMEs during the pendemic crisis. Finally, this study could assist the regulators in governing the policy regarding SMEs in conjunction with the crisis. The article proceeds as follows; Section 2 reviews the literature on SMEs business hurdles during pendemic outbreaks and survival strategies. Section 3 describes the research method. Section 4 presents the findings of the study, and the final section concludes with suggestions for policy maker, industry and future research.

\section{Literature review}

SMEs are the major contributors of Malaysia economy (Zalina et al., 2016). There are 907,065 establishments of SMEs recorded by Small and Medium Enterprise Corporation (SMECorp, 2019). The SMEs segment contributes about $98.5 \%$ of total business establishments across all economic sectors, 36.6\% of Malaysia's GDP and $65.3 \%$ employment in 2016. SMEs are defined as firms with sales turnover not exceeding RM50million or employment not exceeding 200 workers for the manufacturing sector. While, for the services and other sectors, SMEs are firms with sales turnover not exceeding RM20 million or employment not exceeding 75 workers (SMECorp, 2019). With the large numbers of SMEs establishment in the market, any business and economic crisis will inevitably affect various sectors and national economic progress. 
The Covid-19 coronavirus spread has regrettably borne out downside scenarios to global economy and people's activities. China is the first country recorded the spread of the virus with more than 80,000 people infected and World Health Organization (WHO) had declared Covid-19 as a pandemic on March 11, 2020 (Congressional Research Service, 2020. The virus outbreak has spread fast and expected to continue spreading to all parts of the world. Currently, more than 140 countries have reported about 735,000 sickened cases (Congressional Research Service, 2020; Craven et al., 2020) and the cases are increasing exponentially in United State of America, Italy, Germany, France, Iran and other countries (Segal \& Gerstel, 2020). Nevertheless, the governments, businesses, and individuals still have substantial ability to control the disease's progressions through some specific actions (Craven et al., 2020; Smith-Bingham \& Hariharan, 2020).

Movement control, lockdown, confinement and social distancing are amongst the governments' effort to safeguard unprecedented public health and economic responses (Craven et al., 2020). The coronavirus may not swing back fully once the outbreak has relented (Craven et al., 2020). As such, Malaysia has implemented the Movement Control Order (MCO) on March 18, 2020 to March 31, 2020 and later entended to April 14, 2020, in conjuction with the Prevention and Control of Infectious Diseases Act 1988 and the Police Act 1967, to cordon the chain of the virus. The order involved the closure of all government, private and business premises except those in the essential services (the water, electricity, energy, telecommunications, postal, transportation, irrigation, oil, gas, fuel, lubricants, broadcasting, finance, banking, health, pharmacy, fire, prison, port, airport, safety, defence, cleaning, retail and food supply) (The New Straits Times, 2020).

\section{Impacts on economy and SMEs}

Covid-19 is jeopardizing the economic well-being of peoples and institutions (Sneader \& Singhal, 2020). The pendemic does not only affect the global health condition but also impending the structure of global economic order. Consequently, many economies are in the dawn of recession (OECD, 2020). Congressional Research Service (2020) on their latest global economics analysis reported the crisis had trimmed the global economic growth by $0.5 \%$ to $1.5 \%$ as at March 2020. Ernst and Young (2020) in their Global Capital Confidence Barometer survey revealed that $73 \%$ of respondents have perceived severe impact on world economy, while the other $27 \%$ perceived a minor impact. The extensive local and crossborder movement control involving the shutting down of local, national and international business entities are also affected world economy (Smith-Bingham \& Hariharan, 2020). As a result, millions of workers are rest under confinement and businesses are in short supply and struggling to get back the normal track (Smith-Bingham \& Hariharan, 2020; Sneader \& Singhal, 2020). Aviation, tourism, travel-related industries, hotels, restaurants are among the highest disrupted sectors during the $\mathrm{MCO}$, while the staple goods producer, groceries, healthcare, pharmaceutical and agriculture companies are comparatively less vulnerable (OECD, 2020; Segal \& Gerstel, 2020).

The impact of coronavirus on worldwide SMEs business activities are tremendous. Although stringent government policy and response to curb the disease is necessary, but most businesses are expose to negative effects in either short or long-term period. Major hurdles are cash flow problems, closure of operation, laying off workers, retrenchment and diluted firms' capacity for future expansion (Wahyudi, 2014; Craven et al., 2020; Smith-Bingham \& Hariharan, 2020). Changes of business strategies, operations and business conduct, as well as pressures to search for new sources and opportunities for redevelopment are recognize as crucial survival challenges for most SMEs (Cassia \& Minola, 2012; Svatošovă, 2017; Syed, 2019). Nevertheless, the impacts might vary in accordance to the types of business activity, 
size and resources owned (Cassia \& Minola, 2012). As such, there is a critical need to investigate the impact of such phenomena when little evidence is curently available for practioners, policy makers and academia references.

In Malaysia, the Bank Negara Malaysia (BNM) statistics shows that the financial risks of SMEs are already visible during the third and fourth quarter of 2019 , due to the average debt-to-equity ratio stood at $25 \%$ and profit margin of only 5.7\% (BNM, 2020). Thus, the impact of immediate shocks scenarios on business stability are unavoidable. Based on Theedgemarkets.com (2020) online survey on the sustainability among 15,627 Malaysian SMEs reports that most SMEs are very tight in their cash flow and expected to have no cash inflow for at least three months after MCO due to various obligations such as staff salary, rental and other statutory payments. About $33.3 \%$ of SMEs can only have enough cash flow for March while 37.8\% can only sustain up to April (Theedgemarkets.com, 2020). However, comprehensive statistics and official data about the economic impacts of Covid-19 on public and SMEs are still unavailable in Malaysia.

Consequently, for the first time in the world history, tremendeous contingency stimulus funding are offered by most countries to support business sector and their workers (OECD, 2020). For that reason, Malaysian government on 26 March 2020 had launched the PRIHATIN Economic Stimulus Package 2020 with RM3.3 billion budget to assist SMEs in sustaining business operations, employment and domestic investment (Prime Minister's Office of Malaysia, 2020). The funds will be channelled to various sectors via financial institutions including the commercial banks, Islamic banks and other development financial institutions. Special Relief Facility (SRF) from Bank Negara Malaysia amounting RM3.0 billion are allocated to ease SMEs burden in term of short-term cash flows and working capital. The loan packages come with $3.75 \%$ financing rate per annum inclusive with guarantee fees by Syarikat Jaminan Pembiayaan Perniagaan Berhad (SJPP) or Credit Guarantee Corporation (CGC) is dedicated to SMEs with maximum shareholder funds of RM5 million (Prime Minister's Office of Malaysia, 2020).

Recently, Malaysian government had announced the Additional PRIHATIN SME Economic Stimulus Package (PRIHATIN SME+) amounting RM10 billion to respond on the hardship faced by SMEs following the MCO (Muhyiddin, 2020). The additional package is used to support SMEs' cash flow problems. Throughout the new scheme, special allocation of wage subsidies from RM600 to RM1200 per month are introduced for retaining SMEs workforce for the next six months. The new financing facility of RM2.1 billion was also announced in terms of micro enterprises loan with the maximum amount of RM3000 per eligible company.

\section{Resource Based-View Theory (RBV) and SMEs sustainable strategies during business turmoil}

Strategy is recognized as focal organizational resource in determining firm decision, capabilities, competitive-advantages and performance during crisis period (Mahani \& Suraiya, 2019; Azmi et al., 2020). Resource Based-View Theory (RBV) has acknowledge the role of idiosyncratic strategies, firm's resources and specific internal factors as firm resources in uplifting firm's performance and sustainability (Barney, 1991; Warnier et al., 2013). The strategic goals of firm are to develop and deploy a combination of valuable, rare, inimitable and non-substitutable (VRIN) resources to achieve their full economic potential (Enders et al., 2009; Warnier et al., 2013). The framework is appropriate to develop integrated strategies that simultaneously cope with the internal and external perspectives of business strategic decisions (Cassia \& Minola, 2012; Warnier et al., 2013).

More specifically, Chatzoglou et al. (2018) reported the coexistence of strategy, utility effects, firm specific resource capabilities and organizational structure on firm performance 
amongst the Greek SMEs manufacturing companies. The study postulates that structure is prerequisite for successful strategy implementation. The organizational structure relates to the formal configuration of individual and groups within the company in allocating the tasks, responsibilities and power that direct the firm's activities effectively. Other researchers posited that, SMEs' sustainability depends on innovation capabilites, financial resources, networking and technology (Zalina et al., 2016; Mahani \& Suraiya, 2019). Zurinah et al. (2019) concluded that opportunity seeking and maximum effort to uplift the business, determine the SMEs growth.

Svatošová (2017) highlights the importance of crisis, remediation and rescue strategies for SMEs during business turmoil period. The necessary strategies minimize the bankruptcy risk, and bad financial impacts (liquidity, profitability, laverage, etc.). The rescue strategy covers the business conception, production, and searching for new opportunities. Other related remediation strategy relates to "debt forgiveness" and renegotiation strategy with financial institution and debtors as managers concern about firm's cash flow imbalance (Wahyudi, 2014). In case of default risk study among 2,172 SMEs in Indonesia, cash flow problems are identified as the major cause of small firms' liquidity and bankruptcy risk as compared to the larger firms.

In Malaysia, recent study by Azmi et al. (2020) on 348 small and medium enterprises highlights the role of staffs, managerial expertise and financial strength on SMEs resistence during the economic downturn. Empirical investigation by Nur et al. (2014) on the predictors of financially distress amongst 278 SMEs found almost similiar evidence whereby the liquidity, cash flow, firm size, location, business sector and legal form of the enterprises are the predictors of firms' difficulties. Interestingly, the study reveals that Malaysian SMEs relies heavily on long-term and short-term debts to support their total assets and operation. Thus, the debts will give more pressure to the firms during the turmoil period.

\section{Method and study area}

This descriptive study aims to get fresh and meaningful insights on the impact of Covid-19 Movement Control Order (MCO) on SMEs businesses and its connections to the remedial business strategies by the firms. The exploratory had been conducted through the semistructured telephone interview, as it is the safest communication channel during the pandemic outbreak period and will generally gain higher response rate (Jackson, 2008). The total of six SMEs' owners were interviewed. The respondents were selected through the non-probability sampling technique specifically the purposive method, from the the alumni of the entrepreneurship and business development programme of the National University of Malaysia. The location of the respondents was scattered in Klang Valley and other states in Peninsular Malaysia.

This study interviewed six selected respondents, performing different business activities. The wide spectrum of activities helps researchers to have better understanding on the issues of study. All informants (INF) were the owners of the company. The details of each informants and their business profiles are shown in Table 1. The INFs have business experiences in between 7 to 21 years. The paid-up capital of each firms is ranging from RM150,000 to RM1.0 million and annual sales turnover is RM140,000 to RM9.0 million. The total number of permanent staffs recorded is within 4 to 40 . The business profiles met the SMEs definition by the SMECorp (2019). 
Table 1. The profile of respondents and companys' background

\begin{tabular}{|c|c|c|c|c|c|c|c|c|}
\hline Respondent & Gender & $\begin{array}{l}\text { Business } \\
\text { experience }\end{array}$ & Type of business & $\begin{array}{l}\text { Business } \\
\text { location }\end{array}$ & $\begin{array}{l}\text { Paid-up } \\
\text { capital } \\
(' 000)\end{array}$ & $\begin{array}{l}\text { Annual } \\
\text { turnover } \\
(' 000)\end{array}$ & $\begin{array}{l}\text { No. of } \\
\text { permanent } \\
\text { staffs }\end{array}$ & $\begin{array}{l}\text { No. of } \\
\text { subsidiaries } \\
\text { owned }\end{array}$ \\
\hline INF-1 & Male & 21 years & $\begin{array}{l}\text { Telecommunication } \\
\text { systems and training }\end{array}$ & $\begin{array}{l}\text { Cheras, } \\
\text { Kuala } \\
\text { Lumpur }\end{array}$ & RM500 & $\mathrm{RM} 2,500$ & 10 & 1 \\
\hline INF-2 & Female & 12 years & Restaurants and bakery & $\begin{array}{l}\text { Bangi, } \\
\text { Selangor }\end{array}$ & RM150 & RM250 & 8 & - \\
\hline INF-3 & Female & 11 years & $\begin{array}{l}\text { Manufacturer - } \\
\text { healthcare and beauty } \\
\text { products }\end{array}$ & $\begin{array}{l}\text { Shah Alam, } \\
\text { Selangor }\end{array}$ & RM1,000 & RM9,000 & 40 & 2 \\
\hline INF-4 & Male & 7 years & Printing & $\begin{array}{l}\text { Kajang, } \\
\text { Selangor }\end{array}$ & RM900 & RM1,000 & 8 & - \\
\hline INF-5 & Male & 10 years & $\begin{array}{l}\text { Agriculture farm } \\
\text { (vegetables, mushroom } \\
\text { and chicken poultry) }\end{array}$ & $\begin{array}{l}\text { Alor Setar. } \\
\text { Kedah }\end{array}$ & RM150 & RM140 & 4 & - \\
\hline INF-6 & Male & 8 years & Travel agency & $\begin{array}{l}\text { Damansara, } \\
\text { Kuala } \\
\text { Lumpur }\end{array}$ & RM200 & RM3,000 & 5 & - \\
\hline
\end{tabular}

Source: The study

A set of questions are prepared as shown in Table 2. The questions are carefully designed to obtain appropriate evidence to support the research objectives. The question sets are sent to each respondent via the WhatsApp message platform, half an hour before the interview call. By doing so the respondent will be more ready for the interview session. The interview session took about 30 to 40 minutes each and was audio recorded with the informant's permission. The interview transcripts are then analyzed using the content analysis approach where the data was classified, summarized and tabulated. This study follows Austin and Sutton (2015) content analysis procedure, which involved the coding, thematization, summarizing and the intrepretation of data to gather meaningful results.

Table 2: Interview questions

\begin{tabular}{|c|c|}
\hline Informations & Questions \\
\hline $\begin{array}{l}\text { Owner and business } \\
\text { background }\end{array}$ & $\begin{array}{l}\text { 1) Gender } \\
\text { 2) Academic qualifications } \\
\text { 3) Business experience (year) } \\
\text { 4) Type of business and activities } \\
\text { 5) Business location } \\
\text { 6) Paid-up capital } \\
\text { 7) Average turnover (monthly \& yearly) - estimates for the past } 3 \text { years } \\
\text { 8) Number of staffs }\end{array}$ \\
\hline $\begin{array}{l}\text { Impacts and business } \\
\text { strategies }\end{array}$ & $\begin{array}{l}\text { 1) Could you explain how Covid-19 outbreak affect the industry and } \\
\text { business? } \\
\text { 2) What are the overall impacts of Covid-19 and MCO on your existing and } \\
\text { future business directions? } \\
\text { 3) How far the MCO affect your current business operation? } \\
\text { 4) What is the impact of MCO on your company's current financial } \\
\text { positions? } \\
\text { 5) Do the government stimulus packages help your company (if any)? } \\
\text { 6) What is your company's supply chain position since the start of Covid-19 } \\
\text { outbreak in China and during the MCO? } \\
\text { 7) Could you describe about any financial strategies, resources or tactics that } \\
\text { 8) Could your company to survive during and, perhaps after the MCO? } \\
\text { tactics (such as business networking, products differentiation, marketing, } \\
\text { etc) that help your company survive during and, perhaps after the MCO? }\end{array}$ \\
\hline
\end{tabular}

Source: The study 


\section{Findings and discussion}

This section reports the findings and discussion for each objective.

\section{Impacts of $M C O$}

Majority of the respondents highlight their main concerns on the operation distruption during the confinement period [INF-3; INF-4; INF-6] as shown in Table 3. The government order on the closure of all non-essentials business premises had standstill the SMEs in the travelling and printing sector. Other businesses under the essentials industry category for domestic needs and necessities of peoples are continuing their operation, but at a reduced scale. These inevitably led to cash flow problems as reported by Wahyudi (2014), Craven et al. (2020) and the report of Department of Statistics Malaysia (2020). Some companies recorded "zero income" after the total business lockdown during the MCO [INF-2; INF-4; INF-6]. The cash flow imbalance occur as the owners are still obligated to make compulsory expenses such as the staffs' salary, business loans, rental fees, utilities and other fixed costs. Eventhough the commercial banks offered six months moratorium period for all business loans, not all businesses get benefit from the incentive since they are utilizing other types of financing method such as the financial leasing [INF-4].

The business stimulus package (PRIHATIN Economic Stimulus Package 2020 and Additional PRIHATIN SME Economic Stimulus Package or PRIHATIN SME+) launched by the Malaysian government are still at the initial stage as the respondents are waiting for more details on its distribution and applications procedures [INF-4; INF-5]. The evidence is supported by the experience of the printing company owner (INF-4) who mentioned that the monthly asset's lease payment is uncovered under the six months loans moratorium initiative. Therefore, access to financial stimulus package is also an issue to SMEs. Financial distress might expose SMEs with banckruptcy risks [INF-1; INF-6]. The prolonged of the confinement period will probably turn the company into bankcruptcy position. Related factors are the gearing ratio and size of monthly loan's repayment. The higher the gearing ratio and repayment, means the higher banckruptcy risks faced by the company as propounded by Cassia \& Minola (2012) and Svatošovă (2017). From the interviews, almost all SMEs report their financial preparedness to sustain the business is up to the maximum period of three to six months without sales or with sharp drops in cash inflows during the MCO period. The oldest firm under the study [INF-1] report to have capacity to sustain their business up to 12 months if the Covid-19 outbreak still requires for business closedown.

The respondent report that SMEs usually always rely on the supply chain network to operate [INF-3; INF-4; INF-5]. Closure of suppliers' premises and operations, and pending of international trade for raw materials and supplies due to the lockdown in most of the major exporter countries as China was immediately affecting the SMEs' operation. The respondents also reported that their ability to re-design their business direction within a very short period is quite limited [INF-1; INF-3; INF-6]. Certain types of business such as agriculture, restaurant and healthcare possess flexible capabilities and resources that can immediately turn to produce a new product [INF-2; INF-3; INF-5]. However, other businesses such as the travel agency services, telecommunication providers and printing are relatively more difficult to adopt changes due to the rigidness of its resources [INF-1; INF-4; INF-6], thus confirmed the results of Chatzoglou et al. (2018), Mahani \& Suraiya (2019), Azmi et al. (2020) and the Department of Statistics Malaysia (2020).

Table 3 summarized the impacts of MCO on SMEs as discussed above. Based on the interview data, the themes of impact can be identify as, (1) operational disruption; (2) cash 
flow problem; (3) access to stimulus package; (4) risk of bankruptcy; (5) supply chain disruption; (6) problems in foresighting future business direction.

Table 3: Impacts of MCO on businesses

\begin{tabular}{|c|c|c|}
\hline No & Themes of impacts & Interviews' transcription \\
\hline \multirow[t]{3}{*}{1} & $\begin{array}{l}\text { Operation } \\
\text { distruption }\end{array}$ & $\begin{array}{l}\text { "My business is now 100\% stopped. We are not classified under the basic goods } \\
\text { by the government" [INF-4] }\end{array}$ \\
\hline & & $\begin{array}{l}\text { "Since the first day of MCO, we are } 100 \% \text { closed. One is because of the MCO, } \\
\text { second is because there are no customers want to travel in this period". [INF-6] }\end{array}$ \\
\hline & & $\begin{array}{l}\text { "Alhamdulillah... the company is still running well producing our new products, } \\
\text { hand sanitizer and surface disinfectant liquids. However, we just operate with } \\
\text { only } 22 \text { workers a day, instead of } 40 . . \text { following the social-distancing order". } \\
\text { [INF-3] }\end{array}$ \\
\hline \multirow[t]{3}{*}{2} & Cash flow problem & $\begin{array}{l}\text { "We run our restaurant in a university campus. Due to the campus closure, we } \\
\text { lost totally... No income, but have compulsory payment to pay such as staff's } \\
\text { salary, rental and business loans". [INF-2] }\end{array}$ \\
\hline & & $\begin{array}{l}\text { "Sales are zero at this moment, but we have to pay overhead, eight staffs with } \\
\text { fixed salary and lease payment of RM20,000 per month". [INF-4] }\end{array}$ \\
\hline & & $\begin{array}{l}\text { "For March 2020, we still pay full salary for all staffs. Without any incoming } \\
\text { income, company has to bear RM30,000 overhed and payables a month". [INF-6] }\end{array}$ \\
\hline
\end{tabular}

3 Access to stimulus packages

Risk of bankcruptcy

$5 \quad$ Supply chain distruption

$6 \quad$ Problems in foresighting future business direction
"We have yet to apply for any government incentive packages. I am still waiting for further informations from Agriculture Department or AgroBank about how they will chanell the funds to farmers". [INF-5]

"Six months loans moratorium is not including financial lease. I still have to pay our monthly leasing of our machines". [INF-4]

"With current business situation and our reserve, I believed we might survive up to 12 months". [INF-1]

"Insya Allah we hope to sustain for at least 3 to 4 months with our existing savings. I can't predict what is going to happen then”. [INF-6]

"We have limited access to ethanol supplies.. There are small number of suppliers available and raw material, are mostly imported from China, but they are still under lockdown”. [INF-3]

"I still have some small order for products sticker from regular customers, but at this moment, our suppliers cannot deliver raw materials". [INF-4]

"Every week I personally prepared chickens food, named bokashi to save cost and avoid delays of chicken broth delivery by our supplier". [INF-5]

"I'm trying hardly to predict the future of my business whether there is need to change business or implementing new business techniques. I don't know whether we should turn completely online to avoid Covid-19 or not, but certain things need to be face-to-face". [INF-1]

"We can't really predict future direction of this business at this moment. The pandemic was spreaded swiftly... For the time being, we just grab what ever opportunities that comes to us". [INF-3]

"I did not predict we will hit hardly... The lockdown is every where in this world and we do not see any improvement to our business line for next 3 months". [INF6] 


\section{Survival strategy}

This part identifies the survival strategies implemented by the SMEs. There are two identical themes of strategies applied during the MCO situation to keep them afloat. The details are as follows;

\section{a) Theme 1: Financial strategy}

Prior to the Covid-19 MCO period, most of the SMEs have already minimized their debt exposure by utilizing capital rationing in assets acquisition and working capital. This is due to their existing business policy and experience during the changes of government after the general election in 2018. A respondent mentioned that: "Luckily, I had already controlled my debt since 2018 when the payment from our clients are deliberate, just after the general election due to certain change of GLCs procurement and financial process [INF-1]". The second respondent reiterate; "We pay highest down payment as we can in any purchases of assets to avoid any circumstances during business turmoil period. I just have RM200,000 leasing commitment for our three machines whereby we paid more than RM300,000 downpayment for it. [INF-4]". The other respondent says, "Since early March, I had changed the salary scheme of my workers into daily based wages. Luckily, they understood as we want to survive... [INF-5]".

The respondents also adopt business flexibility strategy to maintain their financial position during the confinement period. Quick action, flexible resources and ability to grab new opportunity by venturing into new business lines, products and offerings has quickly sustain the cash flow and avoid the banckruptcy risks. A respondent said: "As we know that there is high demand for hand sanitizer and surface disinfectant liquids, we had stopped all other products and fully concentrated on new products by using the same machines. Since middle of March, we had produced and sells 20,000 units just in 10 days and it helps [INF3]". Meanwhile, another respondent mentioned that; "Our firms has carefully accumulated enough cash reserve to at least covers six months expenses and overhead since last five years. It hard, but now it works [INF-3]".

The effect of PRIHATIN stimulus package as at this point of time is yet to support the SMEs financing strategy. The respondent mentioned that: "as at now, we have yet to apply for any government incentive packages. I am still waiting for further informations from Agriculture Department or AgroBank [INF-5]". The fourth respondent reiterate "...but six months loans moratorium is not including our financial lease. Eventhough our employees will recieve RM600 subsidies on salary, we still need to cover for their full pay. The issue now is we do not have any income [INF-4]". These findings support the role of optimizing internal strategic resources to enhance firm competitive advantage during the turbulence situation (Warnier et al., 2013). Based on the findings, it is clear that the internal ability to manage sudden drops of cashflows varies by the type of business activities and strategic internal resources owned.

\section{b) Theme 2: Marketing strategy}

The second identified theme is the marketing strategy during the Covid-19 MCO period. Although half of the respondents' businesses are totally in lockdown position, the rest of other businesses are still in operation. In term of marketing, two firms are slowly in the process of adapting to the electronic and social media marketing. A respondent highlighted that; "As the coronavirus is still not reach to an end, we must gradually change our sales and marketing channel towards the online platform immediately [INF-1]". The other 
entrepreneur had said; "My new strategy is to pursue with online marketing through Shopee and Lazada as soon as possible [INF-5]".

The other method used in pursuing immediate aggressive marketing strategy is relates to the use of sales sub-agents in every state. One of the statements is; "At present, we already encourage our sales agents at various states to promote both of our new products through their newly recruited sub-agents and online platform. As at March, the strategy seems effective where some of them had secured order up to 200 units per day [INF-3]". The respective respondent is also notifying that; "For surface disinfectant liquids, we sell it in different packaging of one litre up to 20 litres each to ensure customers can get the optimal quantity and price [INF-3]".

These findings reinforced evidence of Zalina et al. (2016) and Mahani \& Suraiya (2019) that business operators and SMEs must embrace innovative marketing platforms and technologies in order to remain resilient during unexpected situation. Thus, the ability to transform and optimize internal resources is recognized as a valuable competency's strategies supported the RBV theory (Barney, 1991; Warnier et al., 2013). As far as RBV is concerned, the internal strategic resources and capabilities vary across different the SMEs. As a result, some of the entrepreneurs are able to switch to alternative financial and marketing strategies, while others are unable to do so. In addition, the uniqueness of resources deployed in business operation may limit the ability of the firm to react promptly to any drastic circumstances or to optimize the generic aids such as in INF-4 situation.

\section{Conclusion}

The purpose of this qualitative study is to seek SMEs' owner thoughts and feelings on the impacts of Malaysian Covid-19 MCO on their business activities and understands the shortterm survival strategies in line with the resource-based perspective. In summary, the SMEs business challenges during the immediate quarantine measures are characterized as operational problems (i.e. operation distruption; supply chain distruption; problems in foresighting the future business direction) and financial related problems (i.e. cash flow problems; access to stimulus packages; risk of bankcruptcy). There is a consensus pattern among the respondents that the major themes of current survival strategies have relate to the financial and marketing strategy that utilize all valuable and strategic resources under their control. Firm's accumulated financial resources are very efficient tools for business sustainability during the crisis period, while other assets and skills allow firms to react to the new business opportunities.

This qualitative study has no attempt to generalize the findings to a wider population. Future research should focus on in-depth analysis and proceed with relevant quantitative study in this area. As for SMEs, we strongly encourage them to get prepared with strong financial reserved and emergency funds to cover at least six months overhead and other fixed costs. SMEs must have certain degree of strategic resources and flexible enough to mobilize during crisis period since modern businesses are expose to various unpredicted global crisis. Investment into technology, apps, online marketing and new delivery system is necessary in unpredictable future of the Covid-19 pendemic crisis. In this moment, government should rapidly strengthen the distribution mechanism of all business-related stimulus packages and disseminate the information clearly. The final measures from various business development agencies is to provide free and confidential business advisory services to SMEs in needy. It will help them to navigate their business smoothly through this difficult situation. 


\section{Acknowledgement}

Special thanks go to respondents and UKM-YCSB for the research grant (EP-2019-055).

\section{References}

Austin, Z., \& Sutton, J. (2015). Qualitative research: Data collection, analysis, and management. The Canadian Journal of Hospital Pharmacy, 68(3): 226-231.

Azmi, W., Aida, I., \& Diana, A.W. (2020). The role of strategic management in growth of small and medium enterprises (SMEs) in Malaysia. e-Bangi Journal of Social Sciences and Humanities, 17(1), 108-124.

Bank Negara Malaysia. (2020). Financial Stability Review Second Half 2019. Retrieved from https://www.bnm.gov.my/ar2019/.

Barney, J.B. (1991). Firm resources and sustained competitive advantage. Journal of Management, 17(1), 99-120.

Cassia, L., \& Minola, T. (2012). Hyper-growth of SMEs towards a reconciliation of entrepreneurial orientation and strategic resources. International Journal of Entrepreneurial Behavior \& Research, 18(2), 179-197.

Chatzoglou, P., Chatzoudes, D., Sarigiannidis, L., \& Theriou, G. (2018). The role of firmspecific factors in the strategy-performance relationship: Revisiting the resource-based view of the firm and the VRIO framework. Management Research Review, 40(1), 46-73.

Congressional Research Service (2020). Global economic effects of Covid-19. Retrieved from https://fas.org/sgp/crs.

Craven, M., Liu, L., Mysore, M., \& Wilson, M. (2020). COVID-19: Implications for business. Executive Briefing, COVID-19: Briefing note, McKinsey \& Company. Retrieved from https://www.mckinsey.com/business-functions/risk/our-insights.

Department of Statistics Malaysia. (2020). Report of Special Survey on Effects of Covid-19 on Economy And Individual (Round 1). Retrieved from https://www.dosm.gov.my/.

Enders, A., König, A., Hungenberg, H., \& Engelbertz, T. (2009). Towards an integrated perspective of strategy: The value-process framework. Journal of Strategy and Management, 2(1), 76-96.

Ernst and Young. (2020). Global Capital Confidence Barometer, $22^{\text {nd }}$ ed. Retrieved from https://www.ey.com/en_my.

Mahani, A., \& Suraiya, I. (2019). Faktor PSiKKIT: Pendorong inovasi pembungkusan dalam kalangan industri kecil dan sederhana berasaskan perusahaan makanan. GeografiaMalaysian Journal of Society and Space, 15(3), 90-103.

Marketing Insight. (2020). Sentiment study on the impact of Covid 19 MCO on Malaysians. Retrieved from https://marketingmagazine.com.my/.

Muhyiddin, M.Y. (2020). Additional PRIHATIN SME Economic Stmulus Package (PRIHATIN SME+), Speech Text - Prime Minister Department. Retrieved from https://pmo.gov.my/2020/04.

Nur, A.H.A., Nasruddin, Z., Abd, H.A., \& Rohani, M.R. (2014). Predictors of financially distressed small and medium-sized enterprises: A case of Malaysia. IPEDR, 76(18), 108112.

OECD. (2020). New OECD outlook on the global economy. Retrieved from https://www.oecd.org/coronavirus.

Prime Minister's Office of Malaysia. (2020). Prihatin Rakyat Economic Stimulus Package (PRIHATIN) Speech Text - Speech by YAB Tan Sri Dato' Haji Muhyiddin Bin Haji Mohd Yassin Perdana Menteri Malaysia. Retrieved from https://www.pmo.gov.my/2020. 
Segal, S., \& Gerstel, D. (2020). The Global Economic Impacts of COVID-19, Critical Questions, Center for Strategic and International Studies (CSIS). Retrieved from https://www.csis.org/analysis.

SMECorp. (2019). SME Annual Report 2018/19. Retrieved from http://www.smecorp.gov.my/ index.php/en/resources.

Smith-Bingham, R, \& Hariharan, K. (2020). This is the impact of the Coronavirus on business. World Economic Forum. Retrieved from https://www.weforum.org/agenda.

Sneader, K., \& Singhal, S. (2020). Beyond coronavirus: The path to the next normal, Article McKinsey \& Company. Retrieved from https://www.mckinsey.com/industries.

Svatošová, V. (2019). Identification of financial strategy in small and medium-sized entrepreneurship. ACTA Universitasis Agriculturae ET Silviculturae Mendelianae Brunensis, 65(4), 1435-1453.

Syed, H.A. (2019). Sustainability in Crisis: Towards Business Continuity in Small and Medium Enterprises. In: Proceedings of the 17th European Conference on ComputerSupported Cooperative Work: The International Venue on Practice-centred Computing an the Design of Cooperation Technologies - Doctoral Colloquium Papers, Reports of the European Society for Socially Embedded Technologies, DOI: 10.18420/ecscw2019_dc10.

Theedgemarkets.com. (2020). Malaysia March manufacturing output dented by Covid-19 pandemic. Retrieved from https://www.theedgemarkets.com/article.

The New Straits Times. (2020). Covid-19: Movement Control Order imposed with only essential sectors operating. Retrieved from https://www.nst.com.my/news.

The Star Online. (2020). Special online survey to study effects of Covid-19 on Malaysians, economy. Retrieved from https://www.thestar.com.my/news/nation/2020/03/23.

Wahyudi, I. (2014). Default risk analysis in micro, small and medium enterprises: Does debt overhang theory occur?. Asian Academy of Management Journal of Accounting and Finance, 10(1), 95-131.

Warnier, V., Weppe, X., \& Lecocq, X. (2013). Extending resource-based theory: considering strategic, ordinary and junk resources. Management Decision, 51(7), 1359-1379.

Zalina, I., Firdaus, A., \& Azman, I. (2016). International business competence and small and medium enterprises. Proceedia-Social and Behavior Sciences, 224, 393-400.

Zurinah, T., Jalaluddin, A.M., Sivapalan, S., \& Yusof, H. (2019). Transformasi memajukan industri kecil dan sederhana (IKS) di kalangan wanita luar bandar. Geografia-Malaysian Journal of Society and Space, 15(4), 151-162. (in Malay) 